\title{
Krzysztof Kornacki Tworzenie obrazu przeszłości w trylogii robotniczej Andrzeja Wajdy
}

\begin{abstract}
Kornacki Krzysztof, Tworzenie obrazu przeszłości w trylogii robotniczej Andrzeja Wajdy [Creating an image of the past in Andrzej Wajda's worker trilogy]. "Przestrzenie Teorii" 27. Poznań 2017, Adam Mickiewicz University Press, pp. 77-91. ISSN 1644-6763. DOI 10.14746/ pt.2017.27.8.
\end{abstract}

Observing the process of the birth of Man of Marble - Man of Iron - Wałęsa. Man of Hope trilogy we can clearly see the author's increasing tendency to render movie fiction real, in the sense that fiction should be treated as reality, as its equivalent. In the two first films in the trilogy, what is visible is the intensified blurring of the lines between fiction and reality, substituting what is fact with something concocted. What we can also see here is a tendency to boost the credibility of a fictional story, thanks to the use of conventions and documentary materials. Gradual changes made in the sphere of art were connected with the director's public activities, in which he gradually crossed the boundaries not only of social, but also political praxis. Moreover, in creating the trilogy we can see a voluntaristic trend to perceive the past as the history of "great men" and to canonize the glorious image of history.

All these tendencies were expressed in the latter work. Wajda completed this as a clear response to political moves by certain politicians and historians attacking Wałęsa. Preparing a movie about him, he approached verification of historical data with a single-minded attitude. Thus in this film we can observe "true fabrications". Wałęsa pervades the story, and there is no room for other important figures in the historical process. Additionally, in order to create an imagined, idealistic image of Wałęsa ("Wałęsa 2.0"), the actor playing this role "expels him" from the archive material.

Gdy na ekrany wchodził film Wałęsa. Człowiek $z$ nadziei, wielu krytyków wskazywało na pozorowany jedynie związek pomiędzy dyptykiem z lat 1976 i 1981 a filmem z 2013 roku. Pamiętano wcześniejsze nieudane próby zrealizowania Człowieka $z$ nadziei (kilka odrzuconych przez Wajdę scenariuszy), na tym tle Wałęsa jawił się jako akt zniechęcenia (sugerował to zresztą sam tytuł, w którym słynna fraza „człowiek z...” stała się podtytułem). Jeśli jednak spojrzeć na film Wajdy z punktu widzenia sposobu konstruowania obrazu przeszłości i odnieść do dwóch wcześniejszych obrazów, można znaleźć wyraźną ciągłość. Inaczej mówiąc: Wałęsa. Człowiek $z$ nadziei w sposobie tworzenia wizerunku historii jest naturalną konsekwencją pracy Wajdy przy dwóch wcześniejszych obrazach. Poza wymienionymi filmami ważnym kontekstem porównawczym będzie dla mnie programowy tekst reżysera na temat rozumienia kina historycznego, stenogram wykładu, który Wajda wygłosił w American University w Waszyngtonie w 1981 roku, gdy przyznawano mu doktorat honoris 
causa. W wykładzie tym wiele miejsca poświęcił Człowiekowi z marmuru i $z \dot{z} e l a z a^{1}$.

Teza moja brzmi: obserwując proces powstawania trylogii, dostrzec można narastającą autorską tendencję do urealniania fikcji filmowej w znaczeniu, w którym fikcja zaczyna być traktowana jak rzeczywistość, jej ekwiwalent. Działo się tak poprzez zacieranie granic pomiędzy fikcją historyczną a faktografią i zastępowanie tego, co faktyczne - tym, co zmyślone. Obok tych zabiegów pojawiła się $\mathrm{w}$ trylogii tendencja do wzmacniania wiarygodności fikcyjnej opowieści poprzez użycie materiałów dokumentalnych. Stopniowe przemiany dokonywane w sferze artystycznej sprzężone były z publiczną działalnością reżysera, w której przekraczał on stopniowo granice sztuki w stronę już nie tylko społecznej, ale też politycznej praxis.

\section{Uhistorycznianie fikcji i fikcjonalizowanie historii}

Podejmując się próby realizacji w 1963 roku Człowieka z marmuru, Wajda pewnie nie przeczuwał, że wejdzie w sam środek polskiej historii, wydarzeń politycznych, które zmieniły jej bieg. Scenariusz Ścibora-Rylskiego z 1963 roku nazwać można defensywnym, jeśli się weźmie pod uwagę, że jedyną jego wartością był opis okresu stalinowskiego: postać Agnieszki była bowiem pasywna, a zakończenie - mało dynamiczne, bez otwarcia na współczesność Polski. Z tej perspektywy patrząc, dobrze się stało, że scenariusz przeleżał trzynaście lat. Od połowy lat 70 . polityka „wlała” się do - wydawało się - już historycznego filmu. Zaczynało się stopniowe przenikanie fikcji i rzeczywistości, wzajemne jej przepływy.

W trakcie realizacji filmu wybuchły strajki w Radomiu i Ursusie. W perspektywie wydarzeń czerwcowych zmienił się status zakończenia wymyślonego przez Wajdę, czyli „dociągnięcie” biografii Birkuta do 1970 roku i jego śmierć w wydarzeniach Grudnia. Gdyby nie było Radomia i Ursusa, Grudzień wieńczyłby pewien historyczny etap robotniczej walki (być może już zamknięty po Gierkowskim „Pomożecie?”), a tak stał się kolejnym jej etapem, nagle zaktualizowanym. Kiedy trwał montaż i udźwiękowianie filmu, powstał Komitet Obrony Robotników. Trudno nie zauważyć że film Wajdy wpisał się idealnie - niemal programowo w postulaty KOR-owców. Nie przypadkiem więc obraz wpadł w oko partyjno-rządowego cyklonu i stał się de facto elementem wielkiej polityki. $\mathrm{W}$ ten sposób fikcja filmowa nabrała bardzo realnego, politycznego zna-

${ }_{1}$ A. Wajda, Moje spotkania z historia, , „Film na Świecie” 1991, nr 4/383, s. 70-76. 
czenia. Oczywiście, nie był to pierwszy film Wajdy który wzbudzał tak silne dyskusje społeczne i polityczne, ale pierwszy, który dotyczył spraw tak silnie związanych z bieżącą polityką, po którym wyższy urzędnik państwowy (Józef Tejchma) musiał ponieść polityczne konsekwencje swoich decyzji ${ }^{2}$.

Trudno było chyba Andrzejowi Wajdzie powstrzymać się przed myślą, że historia szczególnie na niego „poluje”, gdy dowiedział się, że największy strajk w powojennej Polsce wybuchł w sierpniu 1980 roku w miejscu, w którym zakończył Człowieka z marmuru. Po raz kolejny historia wlała się bezceremonialnie w fikcyjne bukłaki. Jak mówił w wywiadzie dla „Przekroju”: „Sierpień sprawił, że historia zaplata się w mój film, który zrobiłem wcześniej. Nastąpiło spotkanie sztuki z życiem i poczułem się zobowiązany, a zarazem upoważniony do tego, żeby nakręcić [kolejny film]”3. Z kolei w „Biuletynie Informacyjnym” Solidarności, a więc jeszcze podczas strajku, opublikowano taką jego wypowiedź:

Zawsze marzyłem o tym, bym mógł zrobić dalszy ciąg tego filmu. Myślę, że byłbym bardzo szczęśliwy, gdyby udało mi się zrobić film, który byłby opowiadaniem o synu bohatera Człowieka z marmuru. Historia syna. Myślę, że w międzyczasie wy dopisaliście tę historię, dopisaliście ją czynami ${ }^{4}$.

Jak wiadomo Wajda dostał od strajkujących zlecenie na Człowieka $z \dot{z}$ elaza.

Stoczniowcy dopisali historię czynami, a Wajda chciał ponownie dopisać historię - w znaczeniu opowieści - do czynów. Chęć związania fikcji z rzeczywistymi zdarzeniami wyraziła się między innymi w pomyśle, aby syn Birkuta był jakąś emanacją postaci Lecha Wałęsa. Kierownik literacki Zespołu „X” Bolesław Michałek sugerował że w scenariuszu filmu analogia do Wałęsy była oczywista ${ }^{5}$. Sam Andrzej Wajda w jednej z notatek z produkcji ubolewał, że „Maciek Tomczyk nie może być Wałęsą”. Pomimo tak jednoznacznego utożsamienia postaci trudno sobie wyobrazić, aby Tomczyk mógł być Wałęsą (postacią przecież powszechnie rozpoznawalną). W zestawieniu Maciek - Wałęsa dopatrzeć się można raczej

2 T. Lubelski, Wajda, Wrocław 2006, s. 170.

${ }^{3}$ Sztuka splotta się z życiem [wypowiedź A. Wajdy], „Przekrój” 1981, 1.03, s. 16.

4 Andrzej Wajda w Stoczni Gdańskiej, „Strajkowy Biuletyn Informacyjny Solidarność”, [w:] B. Michałek, Jak powstawał Człowiek z żelaza, „Kwartalnik Filmowy” 1996, nr 15-16, s. 51-52.

${ }^{5}$ „Czy Maciej Tomczyk jest przywódcą strajku? Kimś w rodzaju Lecha Wałęsy z tych dni? W pierwszej wersji [scenariusza] Ścibora było to niewątpliwe" - tamże, s. 59.

${ }^{6}$ Człowiek $z$ żelaza, Notatki - realizacja, Archiwum Andrzeja Wajdy. Oto dłuższy fragment cytowanej notatki z 18 stycznia 1981 r.: „Maciej nie może być Wałęsą, a Anna Hulewicz p. Walentynowicz, co beznadziejnie komplikuje całe opowiadanie" 
kogoś „podobnego do Wałęsy”, „jak Wałęsa”, a więc przywódcę strajku, jak zresztą nazywa go Wajda w swoich notatkach. Ostateczna decyzja Wajdy, aby całkowicie rozdzielić te postaci i uczynić z Tomczyka jedną z osób rozpoczynających strajk, zwiększyła, paradoksalnie, realizm świata przedstawionego. Gdyby Maciek był przywódcą strajku, łatwo sobie wyobrazić odbiorczy dysonans w sytuacji, w której niemal wszyscy wiedzieli, kto był prawdziwym liderem protestu. Zabieg ten odczuwano by pewnie jako nadmierną fikcjonalizację, pęknięcie w strukturze ontycznej świata przedstawionego. Tymczasem Wajdzie zależało na jego wiarygodności i dzięki ostatecznej decyzji co do statusu postaci Maćka ta wiarygodność, jak wspominałem, wzrosła. Łatwo było bowiem zaakceptować postać z drugiego planu. A jednocześnie, jak wiadomo, umożliwiło to obsadzenie prawdziwych bohaterów tamtych wydarzeń (Wałęsy, Walentynowicz, Fiszbacha i in.) w epizodycznych rolach oraz dużo bardziej płynne „sklejenie” partii dokumentalnych z fikcyjną fabułą. Tym sposobem historyczny realizm filmu wzrósł niepomiernie, bardziej, niż gdyby Tomczyk był kimś a’ la Wałęsa. Ale w ten sposób Wajda ponownie stworzył wiarygodną hybrydę fikcjonalno-faktualną, urealniając fikcyjne postaci. Ten przepływ ontologicznych światów stawał się więc dla Wajdy normą w opracowaniu tematu robotniczego protestu.

Stan wojenny rychło skończył karnawał Solidarności - ale czy Wajda znowu nie miał prawa traktować się jako wybrańca historii, skoro zakończyła się ona tak, jak „profetyczny” finał jego filmu (rozmowa Badeckiego z Winklem pod bramą stoczni)? Sam zresztą po latach nazwał się „prorokiem" (z dystansem właściwym dla poprzedzającego to słowo wielokropka) ${ }^{7}$. Z każdym takim działaniem fikcja zrastała się z rzeczywistością, tworząc historyczny świat możliwy, dla twórcy ważniejszy niż rzeczywisty, będący złożoną kompilacją elementów o różnym statusie ontycznym.

Z czasem ta wizja została przez Wajdę skanonizowana. Emocjonalna siła Sierpnia, moment filmowego i społecznego jednocześnie triumfu, niesłabnąca fascynacja postacią Wałęsy i świadomość, że Człowiek $z$ żelaza jest jednym z najważniejszych ekranowych mitów stworzonych przez reżysera - wszystko to powodowało, że coraz trudniej było Wajdzie myśleć o kontynuacji. Reżyser odrzucał kolejne scenariusze trzeciej części opowieści ze względu na pesymizm w opisie dalszej historii Solidarności. Wajda chciał jej tyrtejskiego obrazu, kanonizacji „złotego wieku” (w efek-

7 „Scena ta w montażu wielokrotnie wypadała pod presją optymistów, którzy domagali się ode mnie bezwzględnego zwycięstwa Solidarności. Ja jednak tuż przed oceną filmu wkleiłem ją ponownie i tak... zostałem prorokiem”, Wajda: filmy, [opr. red. J. Słodowska], Warszawa 1996, t. 2, s. 143. 
cie - dopowiedzmy - fabuła Człowieka z nadziei zatrzyma się na 1989 roku, by nie burzyć tego obrazu). Osiem lat przed premierą Wałęsy. Człowieka $z$ nadziei Wajda zrealizował na potrzeby filmu Solidarność, solidarność (którego produkcję sam zainicjował) nowelę, która jest hołdem dla pierwszego przewodniczącego związku i w której po raz kolejny dochodzi do przemieszania elementów fikcjonalnych i faktualnych. Wajda, jako twórca filmu z 1981 roku, rozmawia z Wałęsą w pustym kinie, w akompaniamencie aktorów odtwarzających postaci Maćka i Agnieszki, a na ekranie pojawiają się inscenizowane fragmenty filmu Człowiek $z$ żelaza łączone z materiałami archiwalnymi z Sierpnia, prezentującymi głównie Wałęsę. Film kończy się napisem „Człowiek z nadziei” nałożonym na fragmenty archiwaliów ze słynnymi wypowiedziami przewodniczącego Solidarności z okresu strajku.

$\mathrm{Z}$ punktu widzenia fabularnego Wałęsę. Człowieka $z$ nadziei trudno uznać za kontynuację dylogii - akcja cofa się do już opisanych czasów, a bohaterem zostaje - jakkolwiek dziwnie to brzmi - postać peryferyjna (stosując współczesną terminologię medialną, można byłoby pewnie powiedzieć, że jest to spin off). Ale oba wcześniejsze filmy Wajdy przestały być dla ich autora tylko filmami, stały się projektami dalece wykraczającym poza krąg sztuki; stały się częścią historii sensu stricto. Dlatego też z punktu widzenia konsekwentnego uhistoryczniania fikcji Człowiek $z$ nadziei jest koniecznym zwieńczeniem dwóch wcześniejszych filmów tym razem jest formą fikcjonalizacji historii; ontyczne wahadło świata przedstawionego wychyliło się w stronę drugiego bieguna.

\section{Faktualizacja fikcji poprzez dokumentalizm}

Proces uhistoryczniania fikcji w dwóch pierwszych filmach wspierał także sposób wykorzystania materiałów archiwalnych i dokumentalnych. O dokumentalizmie w kinie Wajdy pisał już Mirosław Przylipiak. Wskazywał na dwuznaczny, subwersywny charakter partii dokumentalnych zwłaszcza w filmach, w których wprost do dokumentalizmu Wajda się odwoływał (jak Wszystko na sprzedaż czy pierwsze dwie części tryptyku). Przekonywał, że w konfrontacji fikcjonalnego i niefikcjonalnego to ostatnie jest przez Wajdę postponowane - zwycięża przekaz fabularny, historia inscenizowana ${ }^{8}$. Zgadzając się z tą konstatacją, chciałbym spojrzeć na

8 M. Przylipiak, Refleksja nad dokumentalizmem $w$ filmach fabularnych Andrzeja Wajdy, [w:] Kino polskie: reinterpretacje. Historia - ideologia - polityka, red. K. Klejsa, E. Nurczyńska-Fidelska, Kraków 2008, s. 97-118. 
to zagadnienie $\mathrm{z}$ jeszcze innej strony. Po pierwsze, wykorzystywanie dokumentów w tych filmach ma, po prostu, uwiarygodnić świat przedstawiony. Ten postulat przyświecał Wajdzie przy realizacji Człowieka $z \dot{z} e l a z a$, gdy wykorzystywał materiały archiwalne i dokumentalne. Tak jest również $\mathrm{w}$ ostatnim filmie serii. Podczas rozmowy z Tadeuszem Lubelskim o tym właśnie obrazie reżyser mówił: „Byłem głęboko przekonany, że dopiero włączone do całości materiały dokumentalne zapew-

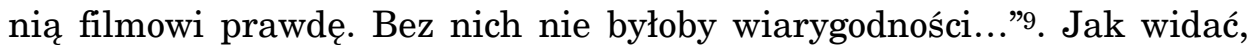
prawda utożsamiona jest tu $\mathrm{z}$ wiarygodnością - bo chodzi o tak zwaną prawdę artystyczną, prawdę przekonywania. Wajda wpisywał się $\mathrm{w}$ ten sposób w tradycję kojarzenia przekazu fotograficznego jako mocnego źródła historycznego, o sile nie tyle nawet eksplikacyjnej, co uwiarygodniającej.

Po drugie, dla niniejszego wywodu ważniejsze, wykorzystanie materiałów dokumentalnych nie tylko uwiarygodniało opowieść, ale miało także wpływ na ontologię świata przedstawionego. Proces ten zaczął się już w Człowieku z marmuru. Zwykle podkreśla się, zresztą słusznie, że stworzenie imitacji propagandowego dokumentu miało na celu zaatakowanie metod ideologicznej manipulacji. Archiwaliów sensu stricto jest $\mathrm{w}$ tym filmie niewiele, a te, które się pojawiają, są fikcjonalizowane, wplecione w opowieść o zmyślonej postaci. I właśnie o ten ontyczny skutek chodzi: fikcyjna postać Birkuta nabiera realności poprzez kontakt z materiałem dokumentalnym. W Człowieku z marmuru dokonuje się pierwszy akt nadawania fikcyjnym postaciom znamion prawdy poprzez odwołanie do dokumentalizmu, potocznie kojarzonego z „twardą” rzeczywistością. Być może nie miało by to takiego znaczenia dla kina Wajdy, gdyby nie fakt, że biografia Birkuta - za sprawą „syna z żelaza” - stawała się coraz bardziej rzeczywista. W Człowieku z żelaza mamy bowiem do czynienia $\mathrm{z}$ procesem faktualizacji fikcji $\mathrm{w}$ jeszcze większym wymiarze, zarówno poprzez przeplatanie inscenizacji z dokumentami, jak i - jak wspominałem - poprzez wykorzystanie prawdziwych, kluczowych dla ówczesnej polityki postaci, w tym Wałęsy i Walentynowicz. Na fikcyjnym ślubie zachowują się tak, jakby rozmawiali z prawdziwymi ludźmi, otwierając przestrzeń dla myślenia o tych ostatnich jako o realnych bytach. Warto pamiętać także o scenie podpisania porozumień sierpniowych, odtworzonej pieczołowicie (jakby była rzeczywistą) $\mathrm{z}$ wpisaniem $\mathrm{w}$ nią postaci Maćka i Agnieszki.

9 Nie tracac nadziei. Z Andrzejem Wajdą rozmawia Tadeusz Lubelski, „Kino” 2013, nr 10, s. 15. 


\section{W stronę polityki}

Przenikanie sztuki i rzeczywistości odbywało się nie tylko w kolejnych częściach trylogii, ale także na poziomie Wajdowskiej biografii. Po zrealizowaniu Człowieka z marmuru Wajda-artysta coraz bardziej angażował się w działalność publiczną, która - w autorytarnej rzeczywistości - stawała się siłą rzeczy działalnością polityczną. W 1978 roku został szefem Stowarzyszenia Filmowców Polskich, stał się orędownikiem demokratycznych zmian w polskiej kinematografii. Kilka dni po strajkach, kilkaset metrów od stoczni (czy to nie kolejny znak historii?), w budynku gdańskiego NOT-u namawiał filmowców do stosowania strategii „mówienia wprost”, „mówienia prawdy” 10 , co w tym systemie znaczyło de facto upolitycznienie filmów. I zanim sam zaczął realizować Człowieka $z$ żelaza, po raz kolejny usytuował się w kręgu wielkiej polityki - reżyserując uroczystość odsłonięcia pomnika Poległych Stoczniowców w grudniu $1980 \mathrm{r}$.

Jako polityczny akt (a nie tylko artystyczny) można potraktować także umieszczenie w Człowieku $z$ żelaza dokumentalnych archiwaliów z Grudnia 1970 roku. Miały ono, poza artystycznym, także praktyczny, rewolterski charakter. Wajda wprowadzał bowiem do publicznego obiegu materiały, które były zakazane przez całą dekadę. Wprawdzie nie był pierwszy (część materiałów zaprezentowano w słynnym numerze Polskiej Kroniki Filmowej z września 1980 roku pt. Strajk), ale oddziaływanie tych materiałów poprzez niezwykle popularnego Człowieka $z$ żelaza było dużo większe ${ }^{11}$.

Krótko po zrealizowaniu Człowieka $z$ żelaza Wajda udzielił symptomatycznego wywiadu dla „Polityki”: „...Ja coraz mniej wierzę, że kino jest najlepszym sposobem oddziaływania na społeczeństwo. W rezultacie odczuwam potrzebę bezpośredniego działania”. Na pytanie „Jakiego działania?” odpowiadał: „Po prostu działania społecznego. Dotychczas nie widziałem dla siebie takiej możliwości” - „A teraz gdzie ją pan znalazł? Komu, czemu, jakiej sprawie chciałby pan służyć?” - „Oczywiście naszemu potężnemu Niezależnemu i Samorządnemu Związkowi Zawodowemu

${ }^{10}$ B. Michałek, dz. cyt., s. 54-57.

11 Notabene: nie zawsze w przywołanej kronice pojawiały się zdjęcia z Grudnia '70; w dokumentach archiwalnych można znaleźć informację o ich braku. Dla przykładu dyrektor Okręgowego Przedsiębiorstwa Rozpowszechniania Filmu w Gdańsku na pytanie Komitetu Założycielskiego NSZZ Solidarność o tę kronikę odpowiadał: „Informuję [...] iż wersja, którą my posiadamy, nie zawiera epizodu z grudnia 1970 r." - Archiwum Państwowe w Gdańsku, Zespół „Neptun Film”, sygn. 3887/159, k. 145. 
Solidarność"12. A w ostatnich słowach cytowanego już wykładu (przypominam, z 1981 roku) Wajda mówił: „Ujawniając, krystalizując to, co ludzi prawdziwie obchodzi, film - cała sztuka, cała kultura - czynić może coś, czego nikt inny nie uczyni: utrwala, nadaje ład i wyraźny kształt świadomości społecznej. A czyniąc to, jest nie tylko rezultatem historycznego procesu, ale stać się może u czestnikiem historii. A może i ws półau torem?" [wyróżn. A. Wajdy] ${ }^{13}$. W stosunku do swojego kina Wajda z pewnością uchyliłby znak zapytania kończący wypowiedź.

Jak wiadomo, reżyser pozostał wierny Lechowi Wałęsie. Jak mówił do niego w noweli z filmu Solidarność, solidarność: „Ja zostałem senatorem na Pańskie wezwanie, dlatego że uważałem, że skoro robię taki film, to muszę też ponieść konsekwencje w moim życiu". W stosunku do Wałęsy Wajda był - mówiąc metaforycznie - sekretarzem wielkiego polityka. Czuł się więc szczególnie uprawniony do reprezentowania jego interesu, przyjmując jednocześnie postawę strażnika dziedzictwa.

\section{Silnie podmiotowa perspektywa opisywania i tworzenia historii}

Warto zwrócić uwagę na jeszcze jeden element, który będzie miał wpływ na sposób prezentacji historii w ostatniej części tryptyku. W tworzeniu ekranowych wizji historycznych odczuwalna jest bardzo silna obecność instancji podmiotowej. Owo ,ja” Wajdy jako historyka (jeśli przyjmiemy na moment, że można go tym mianem obdarzyć) bardzo silnie manifestowało się nie tyle nawet $\mathrm{w}$ fabule, ale $\mathrm{w}$ paratekstach, wywiadach, filmach dokumentalnych, autorskich artykułach. Wajda lubił podkreślać analogie pomiędzy sytuacjami fabularnymi i bohaterami swoich filmów, a nim samym. Tę strategię porównywania własnych losów do losów fikcyjnych postaci Wajda stosował już przy pierwszych swoich filmach, świadczy o tym choćby owo pamiętne „kocham tych nieustępliwych chłopaków" (na okoliczność Popiołu $i$ diamentu) i podkreślanie, że sam mógł być jednym z nich.

Po 1989 roku ten autobiograficzny sposób interpretowania jego dawnych fabuł pojawiał się w publicznym obiegu coraz częściej. W filmie Moje notatki $z$ historii Wajda wyraźnie tworzył różne analogie, na przykład pomiędzy ucieczką i śmiercią Chełmickiego a własnym dramatem, gdy w 1946 roku został złapany przez UB i - jak przekonywał - prowokowany

12 Badźmy dobrej myśli. Z Andrzejem Wajdą rozmawia Krystyna Nastulanka, „Polityka” 1981, nr 22.

${ }^{13}$ A. Wajda, Moje spotkania..., s. 76. 
był do ucieczki, która mogła skończyć się jego śmiercią ${ }^{14}$. (Dodajmy, że na porównaniu fabuły Popiołu $i$ diamentu i opisanego wydarzenia z biografii reżysera oparł swój okolicznościowy artykuł z 1998 roku Rafał Marszałek, tytułując go znamiennie: Watek odnaleziony ${ }^{15}$. Tym nowym interpretacyjnym wątkiem była właśnie biografia reżysera.)

Umieszczenie ujęcia książki Popiót $i$ diament w Tataraku to był oczywiście drobiazg (choć znamienny), ale bardzo rozbudowanych przepływów fikcjonalno-autobiograficznych w Katyniu już nie sposób zlekceważyć (chodzi oczywiście o postać Tadeusza, która jest kontaminacją losów Wajdy i Maćka Chełmickiego). Jak pisałem w innym miejscu,

Wajda prowokuje tą postacią wyobraźnię do tworzenia sieci hybrydycznych skojarzeń, trudnego do rozwikłania kłącza, w którym zaciera się granica pomiędzy realnością a fikcją. W ostatnich filmach wojennych zrealizowanych przez reżysera dochodzi do kontaminacji fikcji i rzeczywistości, do zatarcia granicy pomiędzy nimi, tak, że o postaci fikcyjnej (Chełmicki) Wajda wspomina [...] jak o człowieku realnie istniejącym ${ }^{16}$.

Wajda filmami zrealizowanymi po 1989 roku mówił: byłem tego świadkiem, byłem częściej tej rzeczywistości. A w domyśle - jestem więc szczególnie uprawniony do jej opracowania. Dlatego, gdy zaczynał realizację Człowieka $z$ nadziei, w wywiadzie dla Agnieszki Kublik oznajmiał w sposób ucinający wszelką dyskusję:

Przypominam dzieje Lecha Wałęsy tylko dlatego, że to jest bohater naszych czasów. Bo są nagle jacyś politycy, którzy próbują stworzyć pozory, że ten przywódca robotników był użyty przez kogoś... Wiem, że tak nie było. Ze swoich papierów wiem, że ubecy pisali czasem to, co im przyszło do głowy ${ }^{17}$.

Jak widać, obok historycznej pewności pojawił się argument osobisty - w ten sposób Wajda często generalizował własne doświadczenie ${ }^{18}$. Nie

14 A. Wajda, Moje notatki $z$ historii, „Kwartalnik Filmowy” 1996, nr 15-16, s. 7-21 (tekst jest opracowanym przez redakcje „Kwartalnika Filmowego” zapisem wypowiedzi z filmu dokumentalnego „Andrzej Wajda - moje notatki z historii).

15 R. Marszałek, Moje kino. Popiót i diament. Wątek odnaleziony, „Kino” 1998 r., nr 12 , s. $16-17$.

${ }^{16}$ K. Kornacki, Powroty Wajdy. „Popiót $i$ diament” $w$ filmach reżysera po 1989 roku, „Pleograf” $2006 \mathrm{nr}$ 1, <http://akademiapolskiegofilmu.pl/pl/historia-polskiego-filmu/pleogr af/andrzej-wajda/1/powroty-wajdy-popiol-i-diament-w-filmach-rezysera-po-1989-roku/535> (dostęp: 15.12.2016).

17 Odcyfrowałem Watęsę. Z Andrzejem Wajdą rozmawia Agnieszka Kublik, <http://wy borcza.pl/1,76842,10863646,Andrzej_Wajda_Odcyfrowalem_Walese.html> (dostęp: 15.12. 2016).

$18 \mathrm{~W}$ innym miejscu wspomnianego wywiadu mówi: „Żyję długo i widziałem te wydarzenia na własne oczy. Jak mi opowiadają, że są jakieś dokumenty IPN, to nie chcę tego 
da się ukryć, że takie podejście do przeszłości prowadzić może do historycznego woluntaryzmu (w rozumieniu przeszacowania wyobrażenia narratora, co do kształtu historii). Woluntarystyczne podejście do przeszłości przebija we wspomnianym tekście Wajdy z 1981 roku:

Procesy historyczne notowane są w gabinetach uczonych historyków. Oni ustalają fakty, interpretują związki między nimi, zależności, wpływy, minione koncepcje polityczne, społeczne. Ale tak zawsze było, że nie tylko oni tworzyli wizje tych wydarzeń. Nie tylko od nich zależy, co zwykły człowiek myśli o minionych zdarzeniach i postaciach; nie tylko od nich zależy, jaka jest powszechna świadomość historii. To zależy także - a może przede wszystkim - od artystów, od sztuki, od kultury. Kim byli Cezar i Brutus - wiemy raczej od Szekspira niż od Momsena czy Edwarda Gibbona. [...] Czym był amerykański podbój Dzikiego Zachodu, ów zdumiewający proces tworzenia się nowej cywilizacji na nowych terenach - świat wie przede wszystkim z amerykańskiego westernu ${ }^{19}$.

Można dostrzec metodologiczne pęknięcie zawarte w wywodzie Wajdy - pęknięcie między statusem historyka-badacza a historyka-nauczyciela. Gdy historycy-badacze „ustalają fakty” - dokonują aktu poznawczego, gdy je publikują i popularyzują - stają się kreatorami świadomości historycznej. Wajda zawsze dbał o kształtowanie świadomości, ale często kosztem precyzji w ustalania faktów. Charakterystyczne jest zresztą w cytowanej wypowiedzi to przeszacowanie westernu - jak wiadomo, z punktu widzenia historiografii, raczej mitycznej opowieści mającej wątpliwą wartość eksplikatywną.

Silnie podmiotowa metoda tworzenia wizji historii, prowadząca do woluntaryzmu, łączyła się jednocześnie ze szczególnym przekonaniem Wajdy o roli jednostki w historii (czyli z woluntaryzmem historiozoficznym). Reżyser miał skłonność do personalizacji mechanizmu dziejów i przeszacowania woli i roli wybitnych osobowości. Historiozofii Wajdy przynajmniej tej z późnego okresu twórczości - bliżej było do pocztu wybitnych mężów, niż do podkreślania złożonych czynników społecznych, politycznych, ekonomicznych itp. Warto w tym kontekście zauważyć, jak Wajda widział koleje niektórych swoich filmów: dla międzynarodowych losów Popiołu $i$ diamentu centralną postacią był, zdaniem reżysera, dyrektor Jerzy Lewiński, który miał stracić stanowisko za popieranie jego

słuchać. Opowiem dlaczego. Moja żona Krystyna Zachwatowicz występowała w Piwnicy pod Baranami, kapitan Flaga z SB zajmował się nią i Starym Teatrem, ale go nie znaliśmy. Teraz dostaliśmy z IPN teczki. Zaglądamy, a tam jest napisane, że kpt. Flaga zrobił przeszukanie $\mathrm{w}$ naszym domu i że rozmawiał z panią Zachwatowicz, która powiedziała mu, że nie będzie więcej działać w opozycji. I kapitan Flaga zlikwidował jej teczkę. I ja mam w to wierzyć!?" - tamże.

19 A. Wajda, Moje spotkania..., s. 70. 
filmu ${ }^{20}$. Podobnie myślał o roli Józefa Tejchmy. Tymczasem, nie umniejszając roli tego polityka jako inicjatora filmu Człowiek $z$ żelaza, można zobaczyć jego działania - jak proponuje Andrzej Zawistowski21 - w kontekście ówczesnych walk frakcyjnych.

\section{Zwieńczenie. Wałęsa. Człowiek z nadziei}

Wszystkie wymienione powyżej elementy - zacieranie granic między fikcją a rzeczywistością, naprzemienność i elastyczność ich wykorzystywania, dokumentalizm w służbie historycznego uwiarygodnienia fabuły, polityczne inklinacje reżysera, kanonizacja wizerunku historii, silnie podmiotowa, prowadząca do woluntaryzmu, perspektywa kreowania zarówno wydarzeń historycznych, jak i opowieści historycznej - znalazły swoją materializację w ostatniej części trylogii. Wajda realizował swój przedostatni film jako wyraźną odpowiedź na działania - by wrócić do jego słów - „niektórych polityków” (dodajmy że także historyków), wpisując się tym samym w kontekst polityczny. Przygotowując film o Wałęsie, woluntarystycznie podchodził do weryfikacji historycznych danych (funkcja konsultanta historycznego nie determinowała treści). Wiedział, jak ma wyglądać Wałęsa - a przynajmniej: jak wyglądać nie powinien.

Janusz Głowacki wspominał o wielu nakazach i zakazach, których należało przestrzegać, pisząc scenariusz ${ }^{22}$. I nie chodzi tylko o te momenty z życia Wałęsy, o które historycy toczą spór z powodu braku jednoznacznych źródeł (na przykład zachowanie Wałęsy w grudniu 1970 roku po uwięzieniu czy słynne spóźnienie na strajk). Głowacki i Wajda wypełnili je swoim „prawdziwym zmyśleniem” i jeśli coś może budzić wątpliwość, to brak autorskiej wstrzemięźliwości w tworzeniu obrazu przeszłości z wątłych eksplanacyjnie materiałów. Ale niektóre sceny stały $\mathrm{w}$ sprzeczności $\mathrm{z}$ faktami (np. partia zatrzymania tramwaju tuż koło stoczni przez Henrykę Krzywonos i jej fabularna dominacja w scenie zakończenia pierwszego strajku; nieadekwatne do faktów zachowanie Walentynowicz, która klaszcze, gdy Wałęsa ogłasza jego koniec). Wajda za-

${ }^{20}$ Fakty raczej nie potwierdzają tego przekonania, Jerzy Lewiński pracował w kinematografii jeszcze kilka lat.

${ }^{21}$ A. Zawistowski, Jak rzeźbiono „Człowieka z marmuru”, „Biuletyn Instytutu Pamięci Narodowej" 2010, nr 3, s. 63-68.

${ }^{22} \mathrm{~W}$ tym natury obyczajowej. Po ukazaniu się książki Danuty Wałęsy Marzenia i tajemnica scenarzysta Janusz Głowacki, na prośbę reżysera, dopisywał sceny, które miały ocieplić wizerunek pierwszego przewodniczącego Solidarności - Przyszłem, czyli jak pisaŁem scenariusz o Lechu Watęsie dla Andrzeja Wajdy, Warszawa 2013, s. 106. 
akceptował także zmianę dokonaną przez Głowackiego w metryce pierwszego syna Wałęsy (jak pisał scenarzysta: „prawdę mówiąc, pierworodny urodził się trochę wcześniej, ale pomyślałem, że dla filmu tak będzie lepiej, i podmieniłem mu znak zodiaku"23), a to miało oczywiście wpływ na psychologiczne motywacje działań głównego bohatera (podpisuje ,jakieś papiery”, bo spieszy się do żony w połogu).

Głowacki nazwał te partie „własnym zmyśleniem prawdziwym” (pamiętne określenie Hłaski)24; podobny przykład tworzenia „prawdziwego zmyślenia" podawał Głowacki w innym miejscu swojej wspomnieniowej książki: „Pomyślałem, że śmierć przyjaciela [młodego robotnika Szczepańskiego], nigdy do końca nie wyjaśniona, mogłaby Lecha W. jeszcze bardziej przeciw komunie popchnąć. W rzeczywistości filmowej w każdym razie, a ta jest dla mnie jedynie prawdziwa" 25 . Sądzę, że te ostatnie słowa dobrze charakteryzują także podejście Wajdy do kreacji wizji historycznej. Najprawdziwsza jest rzeczywistość intencjonalnie ukształtowanej fikcji filmowej, będąca wyrazem niezłomnego przekonania reżysera nie tylko co do kształtu przeszłości, ale i co do sposobu, w jakim powinna zostać zapamiętana. W ten sposób sfera faktów łączy się ze sferą wartości (w sposób zresztą charakterystyczny dla gatunku filmu historycznego, w tym biograficznego, jak pisał o tym między innymi Rafał Marszałek ${ }^{26}$ ).

Warto też dostrzec, na co wskazywali krytycy, że postać Wałęsy wypełnia film po brzegi (konkuruje z nim jedynie Danuta Wałęsowa), nie ma nim miejsca dla innych, ważnych dla procesu historycznego postaci, które są - poza nielicznymi wyjątkami - nierozpoznawalne (a jeśli rozpoznawalne, to epizodyczne). W filmie z 2013 roku Wałęsa i protest robotniczy to jedno - Wajda tym sposobem wpisywał się w historiozofię „wielkich mężów".

Jeszcze ciekawszy niż w dwóch poprzednich filmach jest sposób wykorzystania materiałów archiwalnych. Obok traktowania materiałów found footage jako formy ilustracji ówczesnych wydarzeń politycznych pojawia się interesujący zabieg będący swego rodzaju odwrotnością scen z Człowieka z żelaza. Oto fikcyjne postaci Tomczyka i Agnieszki podają w kolejce SKM Wałęsie-Więckiewiczowi do ręki ulotkę. W konsekwencji w kolejnej scenie Wałęsa pojawia się w mieszkaniu opozycjonistów i zaczyna się jego przygoda z Wolnymi Związkami Zawodowymi. I tak to pomiędzy postacią rzeczywistą a postacią zmyśloną znika różnica -

23 Tamże, s. 92.

24 Tamże, s. 29.

25 Tamże, s. 110 .

26 R. Marszałek, Filmowa pop-historia, Kraków-Wrocław 1984. 
obie stają się częścią historii (a widz po raz kolejny styka się z ontyczną hybrydą)

Ale najciekawszy (i najbardziej brzemienny w skutki) jest zabieg, w których aktor odtwarzający postać Wałęsy „wyrzuca” go z materiału archiwalnego! Oczywiście, intencja takiego rozwiązania płynęła pewnie przede wszystkim z chęci zachowania ciągłości fabularnej/fikcjonalnej, niechęci do burzenia iluzji w sytuacji, gdy nagle pojawiłaby się filmowe zdjęcia prawdziwego Wałęsy. Ale przecież można mówić też o ontologicznej konsekwencji takiego rozwiązania: oto Wałęsa zostaje „podmieniony” przez Więckiewicza grającego Wałęsę. Jak pisał Piotr Witek: „[...] Fabularny Lech Wałęsa w wersji Więckiewicza przestaje być postacią wykreowaną i wymodelowaną przez filmową fikcję, a zaczyna się jawić jako analogon/symulacrum postaci historycznej przedstawianej $\mathrm{w}$ filmach dokumentalnych"27. Czy to źle? Dla Andrzeja Wajdy niekoniecznie. Wajda chciał bowiem wykreować „Wałęsę ulepszonego", "Wałęsę w wersji 2.0” - na obraz i podobieństwo swoich wyobrażeń; przynajmniej tych dotyczących jego roli w procesie społecznego protestu i narodowego wyzwolenia. Głowacki wspominał: „O ile wiem, Andrzej Wajda się długo wahał, czy Borys Szyc, czy Robert Więckiewicz. Obaj byli na próbnych zdjęciach świetni. Borysa w ogóle w charakteryzacji nie poznałem. Był Wałęsą. Ale Więckiewicz był lepszy od Wałęsy i bardziej fizycznie pasował"28 [wyróżn. K.K.]. Konstatacja o jakościowej wyższości kreacji aktora od prawdziwej postaci pojawiła się także w ustach samego Wajdy. W jednym z cytowanych wywiadów na stwierdzenie: „Ale Więckiewicz mówi zupełnie jak Wałęsa!” Wajda dodawał: „On mówi lepiej niż Wałęsa. To jest wspaniałe"29. Rzeczywiście, kreacja Więckiewicza oczyszczona jest z tych charakterystycznych dla Wałęsy, czasem irytujących, potknięć, zająknięć, niekontrolowanych przeinaczeń.

Na pytanie, czy Wajda jest historykiem, Piotr Witek tytułem swojej książki odpowiadał (jeszcze za życia reżysera) w sposób twierdzący ${ }^{30}$. Przy czym zastrzegał, że jest to historyk niekonwencjonalny, analogicznie do historii niekonwencjonalnej (a więc tej, która znajduje swoją ewokację nie $\mathrm{w}$ historiografii, ale $\mathrm{w}$ innych, głównie audiowizualnych, tekstach

27 P. Witek, Andrzej Wajda jako historyk. Metodologiczne studium z historii wizualnej, Lublin 2016, s. 457.

28 J. Głowacki, dz. cyt., s. 101.

${ }^{29}$ Odcyfrowatem Watęse..., dz. cyt.

${ }^{30}$ P. Witek, dz. cyt. 
kultury). Piotr Witek, przypomnijmy, to zwolennik konstruktywistycznego zwrotu w metodologii badań historycznych (w tym zwolennik historiofotii). Opis historyczny jest więc konstrukcją, a nie rekonstrukcją, a historyk jest tym, który tworzy „historyczne światy możliwe”. Można by więc uzasadnić Wajdowską metodę tworzenia obrazu przeszłości, odwołując się do tej właśnie metodologii (tak jak czyni to w swojej książce rzeczony badacz).

Można by, gdyby nie pewna obiekcja: otóż Wajda był wyznawcą tradycyjnej historiografii (dał temu wyraz choćby w cytowanych wykładzie), nie mówił, że historia to tylko interpretacja, zdecydowanie częściej używał pojęć, które wydaja się dziś anachroniczne, takie choćby jak prawda (w domyśle historyczna). Oczywiście, wobec zarzutów o fałsz historyczny mógł sięgnąć do nomenklatury konstruktywistycznej - byłoby to ciekawe alibi. Ale Wajda tego nie robił, bo wierzył w prawdę historyczną. A jednocześnie, że jest to prawda, którą on posiadł. Trzeba więc chyba w odniesieniu do Wajdy zaakceptować raczej paradoksy jego „zmyślonej historii prawdziwej".

\section{ARCHIWA}

Archiwum Andrzeja Wajdy w Krakowie.

Archiwum Państwowe w Gdańsku, Zespół „Neptun Film”.

\section{LITERATURA}

Bądźmy dobrej myśli. Z Andrzejem Wajdą rozmawia Krystyna Nastulanka, „Polityka" 1981, nr 22.

Głowacki J., Przyszłem, czyli jak pisałem scenariusz o Lechu Wałesie dla Andrzeja Wajdy, Warszawa 2013.

Kornacki K., Powroty Wajdy. „Popiót $i$ diament” $w$ filmach reżysera po 1989 roku, „Pleograf” $2006 \mathrm{nr}$ 1, <http://akademiapolskiegofilmu.pl/pl/historia-polskiego-fil $\mathrm{mu} /$ pleograf/andrzej-wajda/1/powroty-wajdy-popiol-i-diament-w-filmachrezysera-po-1989-roku/535> (dostęp: 15.12.2016).

Lubelski T., Wajda, Wrocław 2006.

Marszałek R., Filmowa pop-historia, Kraków-Wrocław 1984.

Marszałek R., Moje kino. Popiót i diament. Wątek odnaleziony, „Kino” 1998., nr 12, s. $16-17$.

Michałek B., Jak powstawał „Człowiek z żelaza”, „Kwartalnik Filmowy” 1996, nr 15-16 , s. $47-82$.

Nie tracac nadziei. Z Andrzejem Wajdą rozmawia Tadeusz Lubelski, „Kino” 2013, nr 10, s. $12-15$. 
Odcyfrowałem Wałęsę. Z Andrzejem Wajdą rozmawia Agnieszka Kublik, <http://wy borcza.pl/1,76842,10863646,Andrzej_Wajda_Odcyfrowalem_Walese.html> (dostęp: 15.12.2016).

Przylipiak M., Refleksja nad dokumentalizmem w filmach fabularnych Andrzeja Waj$d y$, [w:] Kino polskie: reinterpretacje. Historia - ideologia - polityka, red. K. Klejsa, E. Nurczyńska-Fidelska, Kraków 2008, s. 97-118.

Sztuka splotta się z życiem [wypowiedź A. Wajdy], „Przekrój” 1981, 1.03, s. 16.

Wajda A., Moje notatki $z$ historii, „Kwartalnik Filmowy” 1996, nr 15-16, s. 7-21.

Wajda A., Moje spotkania z historia, „Film na Świecie” 1991, nr 4 (383), s. 70-76.

Wajda: filmy, red. J. Słodowska, Warszawa 1996, t. 2.

Witek P., Andrzej Wajda jako historyk. Metodologiczne studium z historii wizualnej, Lublin 2016.

Zawistowski A., Jak rzeźbiono „Człowieka z marmuru”, „Biuletyn Instytutu Pamięci Narodowej" 2010, nr 3, s. 63-68. 
